Halaman 37-46

\title{
Pengaruh Penggunaan Active Knowledge Sharing terhadap Hasil Belajar Biologi Ditinjau dari Gaya Belajar Siswa Kelas X SMA Negeri Kebakkramat Tahun Pelajaran 2012/2013
}

The Effect of the Implementation of Active Knowledge Sharing on Students' Achievement in Biology Observed from Students' Learning Style of Class X at SMA Negeri Kebakkramat in Academic Year 2012/2013

\author{
Mardiayu Anggrahini ${ }^{a}$, Maridi ${ }^{\text {b }}$, Joko Ariyanto ${ }^{\text {c }}$ \\ a Pendidikan Biologi FKIP UNS, Email: ayu_acces@yahoo.co.id \\ ${ }^{\mathrm{b}}$ Pendidikan Biologi FKIP UNS, Email: maridi_uns@yahoo.co.id \\ ${ }^{c}$ Pendidikan Biologi FKIP UNS, Email: joko_ariyanto_30@yahoo.com
}

Diterima 4 Juli 2013, disetujui 2 Desember 2013

\begin{abstract}
This research is aimed to find out : (1) the effect of the implementation of Active Knowledge Sharing on student achievement in Biology at the grade of Class X at SMA Negeri Kebakkramat; (2) the effect of students' learning style on student achievement in Biology at the grade of Class X at SMA Negeri Kebakkramat; and (3) the interaction between learning strategy and learning style simultaneously on student achievement in Biology at the grade of Class X at SMA Negeri Kebakkramat. The research belonged to quasi experiment which use Posttest Only Non-Equivalent Control Group Design while the students' achievement in Biology was the dependent variable. The population of this research was all student of Class X at SMA Negeri Kebakkramat in Academic Year 2012/2013. The sample of this research were the students of class $X-1$ as the control group and the students of class X-4 as the experimental group that were taken by cluster sampling. The data of the students' achievement were completed by test, school documents, questionnaires and observation techniques. The analysis technique of this research was two away anava in different cell. The results of hypothesis testing strategies on student achievement is 0.000 for cognitive domains, 0.001 for affective domains, and 0.029 for psychomotor domains. The results of hypothesis testing learning style on student achievement is 0.179 for cognitive domains, 0.759 for affective domains, and 0.538 for psychomotor domains. The results of hypothesis testing of interaction strategies and learning styles on student achievement is 0.538 for cognitive domains, 0.716 for affective domain, 0,879 for psychomotor domains. The conclution of the research were 1) Active Knowledge Sharing strategy has significant effect toward biology's student achievement of Class X at SMA Negeri Kebakkramat; 2) Learning style does not have significant effect toward biology's student achievement of Class X at SMA Negeri Kebakkramat; 3) There is no interaction between learning strategy and learning style toward biology's student achievement of Class X at SMA Negeri Kebakkramat.
\end{abstract}

Key Words: Active Knowledge Sharing, Learning Style, Student Achievement In Biology

\section{Pendahuluan}

Belajar merupakan usaha secara sadar melalui berbagai macam proses belajar yang dilakukan masing-masing individu untuk memperoleh berbagai macam kemampuan dan keterampilan yang akhirnya akan menghasilkan perubahan tingkah laku. Pada proses belajar akan diperoleh perubahan tingkah laku sebagai hasil dari pengalaman individu dalam interaksi dengan 
lingkungannya. Perubahan tingkah laku ini menyangkut aspek kognitif, afektif, dan psikomotorik. Perubahan tingkah laku tersebut dapat kita peroleh dengan memperhatikan berbagai macam faktor yang mempengaruhi proses pembelajaran, baik faktor yang berasal dari dalam diri maupun faktor yang berasal dari luar individu.

Pembelajaran merupakan usaha sadar dan disengaja oleh guru untuk membuat siswa belajar dengan cara melibatkan faktor internal dan faktor eksternal yang ikut serta dalam mempengaruhi ketercapaian hasil belajar. Slameto (2003) menjelaskan faktor yang mempengaruhi belajar ada dua macam, yaitu faktor internal dan faktor eksternal. Faktor internal berasal dari dalam diri siswa yang meliputi faktor psikologi dan fisik siswa tersebut, sedangkan faktor eksternal berasal dari lingkungan belajar yang meliputi suasana, budaya belajar, tempat belajar dan strategi pembelajaran yang diterapkan oleh guru.

Pada kegiatan pembelajaran diharapkan tujuan pembelajaran dapat tercapai dengan maksimal baik dalam aspek kognitif, afektif, maupun psikomotorik. Pada umumnya, beberapa guru masih mengutamakan pencapaian ranah kognitif. Dalam hal ini, yang terpenting adalah guru mampu menyampaikan materi secara menyeluruh kepada siswa dan hasil tes kognitif yang diperoleh siswa baik. Fenomena yang terjadi di beberapa sekolah adalah guru hanya memenuhi kewajiban mengajar dengan target waktu yang telah ditetapkan sehingga guru lebih banyak menyampaikan materi. Hal ini membuat kurangnya keterlibatan siswa dalam proses pembelajaran yang berakibat pemahaman konsep siswa menjadi kurang optimal.

Pada kegiatan pembelajaran, faktor internal maupun faktor eksternal yang mempengaruhi proses pembelajaran harus diperhatikan, agar tujuan pembelajaran dapat tercapai dengan optimal. Salah satu faktor internal yang berasal dari dalam diri siswa yang perlu diperhatikan adalah gaya belajar (learning style). Pada pembelajaran klasikal, guru menganggap semua siswa sama dalam segala hal, seperti kemampuan, gaya belajar, kecepatan pemahaman, motivasi belajar, dan lain sebagainya. Pada kenyataannya karakter siswa sangat berbeda antara siswa yang satu dengan siswa yang lain. Setiap siswa memiliki tingkat kemampuan yang berbeda dalam memahami dan menyerap pelajaran, karena itu masing-masing siswa akan menempuh cara yang berbeda untuk menangkap dan menyerap materi pelajaran. Namun dengan keterbatasan sarana dan prasarana yang menunjang 
proses pembelajaran tersebut, tidak memungkinkan untuk seorang guru membimbing siswa dengan gaya belajar yang berbeda-beda.

Siswa menerima pelajaran dengan menggunakan seluruh alat indra yang dimilikinya, hanya saja ada satu atau dua alat indra yang lebih dominan digunakan oleh siswa. Deporter dan Mike (2010) membagi gaya belajar menjadi tiga, yaitu gaya belajar auditori, visual, dan kinestetik. Siswa yang memiliki gaya belajar auditori lebih suka belajar dengan cara mendengarkan, berbicara, ataupun dialog batin. Siswa yang memiliki gaya belajar visual lebih tertarik untuk membaca materi, belajar melalui melihat secara langsung, atau membuat visualisasi. Siswa yang memiliki gaya belajar kinestetik lebih suka melakukan sesuatu ataupun merasakannya.

Siswa akan belajar dengan maksimal apabila dalam proses pembelajaran siswa merasa cocok antara gaya belajar yang dimiliki dengan strategi pembelajaran yang digunakan guru dalam proses pembelajaran. Strategi pembelajaran yang sesuai akan meningkatkan partisipasi siswa untuk berperan aktif dalam proses pembelajaran. Siswa yang lebih tertarik mengikuti pembelajaran, maka hasil belajar yang dimiliki siswa juga akan lebih maksimal apabila dibandingkan dengan siswa yang kurang tertarik mengikuti pembelajaran.

Suasana belajar seharusnya menyenangkan, sehingga informasi baru akan diterima oleh siswa dengan baik. Pembelajaran aktif berarti siswa mendominasi aktivitas dalam pembelajaran. Siswa lebih berperan untuk memperoleh pengetahuan yang siswa perlukan, sehingga siswa dapat lebih mengoptimalkan kemampuan yang dimiliki untuk mendapatkan pengetahuan yang akan diperoleh. Siswa dapat lebih mengoptimalkan penggunaan alat-alat indra yang dimiliki dalam proses pembelajaran, sehingga proses pembelajaran menjadi lebih efektif bagi siswa.

Secara umum, proses pembelajaran di sekolah, siswa belum dapat berperan secara aktif dan masih bergantung pada guru. Untuk lebih mengoptimalkan proses pembelajaran tersebut, guru diharapkan dapat menggunakan berbagai macam strategi yang tidak monoton yang dapat membuat siswa lebih aktif dalam proses pembelajaran tersebut. Pada proses pembelajaran, peran siswa lebih diutamakan daripada peran guru. Guru hanya berperan sebagai fasilitator dan motivator, yang bertugas membuat siswa lebih tertarik pada pembelajaran dan membantu siswa untuk menemukan 
konsep yang benar. Sebagai peran utama dalam proses pembelajaran, siswa yang akan menentukan bagaimana proses pembelajaran tersebut berlangsung, siswa akan lebih aktif dengan cara yang mereka tentukan sendiri untuk mengikuti proses pembelajaran.

Usaha untuk mengoptimalkan penggunaan potensi yang dimiliki oleh siswa dalam kegiatan belajar adalah dengan menggunakan pembelajaran aktif (active learning). Selain itu, pembelajaran aktif juga dimaksudkan untuk menjaga konsentrasi siswa agar tetap tertuju pada proses pembelajaran. Salah satu strategi pembelajaran aktif yang dapat meningkatkan peran siswa dalam proses pembelajaran adalah strategi pembelajaran Active Knowledge Sharing (Saling Tukar Pengetahuan). Penggunaan strategi Active Knowledge Sharing membuat siswa semakin aktif dan lebih mengoptimalkan potensi yang ada di dalam dirinya. Siswa dapat menggunakan gaya belajar yang dimiliki dalam proses pembelajaran. Karena pada strategi ini siswa yang akan menentukan bagaimana cara siswa belajar, sedangkan teman dan guru akan berperan sebagai fasilitator yang akan membantu dalam proses pembelajaran. Kelebihan dari strategi ini dapat mendukung proses pembelajaran siswa dengan berbagai macam gaya belajar, karena dalam strategi ini siswa dengan gaya belajar visual dapat belajar ketika menyampaikan pendapatnya, siswa dengan gaya belajar auditori dapat belajar ketika mendengarkan pendapat siswa lain dalam berdiskusi, siswa dengan gaya belajar kinestetik dapat belajar dengan berinteraksi dengan siswa lain.

\section{Metode Penelitian}

Penelitian dilaksanakan di SMA Negeri Kebakkramat pada semester genap tahun pelajaran 2012/2013. Populasi dalam penelitian ini adalah seluruh siswa kelas X SMA Negeri Kebakkramat tahun pelajaran 2012/2013. Penelitian ini merupakan kuasi eksperimen menggunakan desain penelitian Posttest Only Nonequivalent Control Group Design. Pengambilan sampel dilakukan dengan cara cluster sampling. Dari 8 kelas diambil 2 kelas yaitu kelas X4 sebagai kelompok eksperimen dengan pembelajaran aktif Active Knowledge Sharing dan kelas X1 sebagai kelompok kontrol dengan pembelajaran konvensional.

Variabel bebas pada penelitian ini adalah strategi pembelajaran Active Knowledge Sharing dan gaya belajar siswa. Variabel terikat pada penelitian ini yaitu hasil belajar biologi dalam tiga ranah, yaitu kognitif, afektif, dan 
psikomotor. Materi yang digunakan saat proses pembelajaran adalah materi limbah. Teknik pengumpulan data pada penelitian ini adalah dokumentasi, tes, observasi, dan angket. Teknik tes digunakan untuk mengambil data hasil belajar biologi ranah kognitif. Metode angket digunakan untuk mengambil data gaya belajar siswa. Dokumentasi pada penelitian ini berupa dokumen nilai UAS semester 1 yang digunakan untuk mengetahui keseimbangan kemampuan awal siswa. Metode observasi digunakan untuk mengambil data hasil belajar ranah afektif dan psikomotor.

Instrumen penelitian berupa soal kognitif dan lembar observasi yang telah diujicobakan untuk diketahui validitas, reliabilitas, daya beda dan taraf kesukarannya. Analisis data pada penelitian ini menggunakan anava dua jalan pada sel yang tidak sama dengan uji General Linear Model yang sebelumnya telah di uji dengan uji normalitas menggunakan uji Anderson-Darling dan homogenitas dengan uji Levene's.

\section{Hasil dan Pembahasan}

1. Pengaruh strategi pembelajaran ative knowledge sharing terhadap hasil belajar biologi

Tabel 1. Pengaruh Strategi Active Knowledge Sharing terhadap Hasil Belajar Biologi

\begin{tabular}{lll}
\hline Ranah & $\boldsymbol{P}$-value & Keputusan \\
\hline Kognitif & 0,000 & Ho ditolak \\
Afektif & 0,001 & Ho ditolak \\
Psikomotor & 0.029 & Ho ditolak \\
\hline
\end{tabular}

Berdasarkan Tabel 1, ada perbedaan rata - rata hasil belajar biologi ranah kognitif, afektif dan psikomotor berdasarkan strategi pembelajaran (kelompok kontrol dengan pembelajaran konvensional dan kelompok eksperimen dengan pembelajaran aktif Active Knowledge Sharing sehingga dapat diartikan bahwa penggunaan Active Knowledge Sharing berpengaruh terhadap hasil belajar biologi ranah kognitif, afektif dan psikomotor.

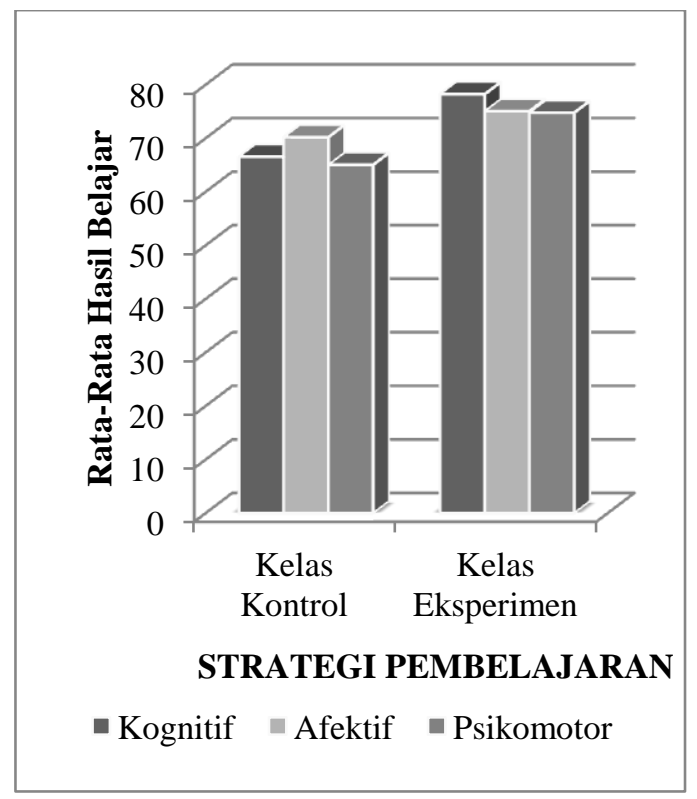

Gambar 1. Perbandingan HasilBelajar Biologi Kelas Kontrol dan Kelas Eksperimen 
Berdasarkan gambar di atas, diketahui bahwa rata-rata nilai hasil belajar biologi (kognitif, afektif, psikomotor) dengan pembelajaran Active Knowledge Sharing lebih tinggi dibandingkan rata-rata nilai hasil belajar biologi pada pembelajaran konvensional. Hal tersebut dikarenakan pembelajaran Active Knowledge Sharing dapat meningkatkan partisipasi siswa dalam proses pembelajaran. Siswa akan berperan aktif saat proses pembelajaran dengan saling bertukar pengetahuan antarteman, sehingga akan mengoptimalkan kemampuan yang dimiliki siswa yang berakibat meningkatnya hasil belajar siswa. Hal ini sesuai dengan pernyataan Silberman (1996) yang menyatakan bahwa Active Knowledge Sharing adalah sebuah cara yang baik untuk menarik para siswa pada materi pembelajaran serta dapat digunakan untuk mengukur tingkat pengetahuan para siswa.

Hal ini juga didukung oleh penelitian yang dilakukan Zahroyani (2011) yang menyatakan bahwa penggunaan strategi Active Knowledge Sharing mampu meningkatkan aktivitas belajar biologi pada siswa kelas VII SMP Negeri 5 Karanganyar.

Strategi pembelajaran Active Knowledge Sharing dapat menumbuhkan komunikasi dan interaksi antarsiswa.
Interaksi antarsiswa terjadi ketika mereka saling betukar pengetahuan untuk memecahkan permasalahan yang diberikan guru sehingga secara tidak langsung mereka saling melengkapi jawaban. Hal tersebut sesuai dengan prinsip saling tukar pengetahuan (knowledge sharing) yang diungkapkan oleh Aurilla Bechina (2006), menyatakan bahwa saling tukar pengetahuan dapat didefinisikan sebagai suatu proses pertukaran pengetahuan antarsiswa, siswa yang tahu (paham) menyampaikan hal yang dia ketahui kepada teman lain sedangkan siswa yang tidak tahu berusaha mencari tahu pada teman yang lebih tahu. Hal ini dilakukan agar dapat memecahkan permasalahan yang diberikan guru dan menemukan jawaban yang berkaitan dengan materi pelajaran.

\section{Pengaruh gaya belajar pada hasil belajar biologi}

Tabel 2. Uji Analisis Pengaruh Gaya Belajar terhadap Hasil Belajar

\begin{tabular}{lcl}
\hline Ranah & $\boldsymbol{P}$-value & Keputusan \\
\hline Kognitif & 0,000 & Ho diterima \\
Afektif & 0,001 & Ho diterima \\
Psikomotor & 0.029 & Ho diterima \\
\hline
\end{tabular}

Berdasarkan tabel di atas dapat diketahui bahwa analisis yang telah dilakukan tidak ada perbedaan hasil belajar biologi (kognitif, afektif, psikomotor) ditinjau dari gaya belajar siswa. Hal ini dapat diartikan bahwa 
tidak ada pengaruh gaya belajar siswa terhadap hasil belajar biologi.

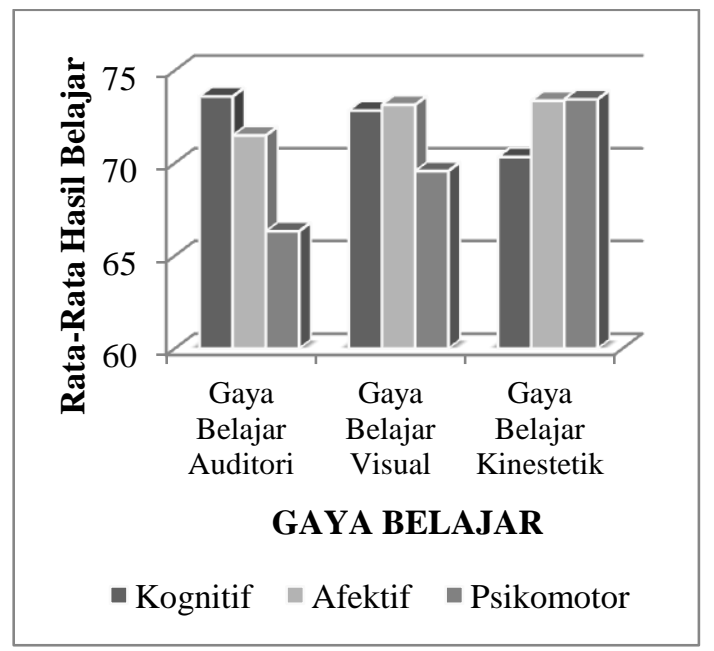

Gambar 2. Perbandingan Hasil Belajar Biologi Kelompok Gaya Belajar Auditori, Visual, dan Kinestetik

Berdasarkan gambar di atas, diketahui bahwa gaya belajar tidak berpengaruh terhadap hasil belajar ranah kognitif, afektif, dan psikomotorik. Hal tersebut dikarenakan ketiga jenis gaya belajar, yaitu gaya belajar auditori, visual, dan kinestetik muncul seimbang selama proses pembelajaran berlangsung.

Hasil uji hipotesis menunjukkan bahwa gaya belajar tidak berpengaruh terhadap hasil belajar ranah kognitif. Hasil belajar ranah kognitif lebih menekankan pada pemahaman siswa. Menurut pengamatan pada siswa, siswa memiliki cara yang berbeda-beda dalam menyerap materi. Ketika proses praktikum terlihat ada siswa yang lebih senang melakukan pengamatan, berdiskusi dengan teman yang lain, dan ada yang lebih suka berbicara di depan menyampaikan hasil diskusi.

Berdasarkan hasil uji hipotesis diketahui bahwa gaya belajar tidak berpengaruh terhadap hasil belajar siswa pada ranah afektif. Penggunaan gaya belajar yang sesuai dalam proses pembelajaran akan membantu siswa menunjukan sikap ketelitian, jujur, disiplin, kerja sama yang baik. Hal ini sesuai dengan pendapat Penger \& Tekavcic (2008), mengemukakan bahwa penggunaan gaya belajar yang sesuai dalam suatu proses pembelajaran akan mempengaruhi peningkatan hasil belajar dan sikap siswa terhadap pembelajaran.

Hasil uji hipotesis menunjukkan bahwa gaya belajar tidak berpengaruh terhadap hasil belajar siswa pada ranah psikomotor. Berdasarkan hasil pengamatan, keterampilan menyampaikan hasil diskusi di depan kelas lebih mengarah ke gaya belajar auditori. Keterampilan mengamati pada saat praktikum lebih mengarah pada gaya belajar visual. Sedangkan interaksi antara siswa selama proses pembelajaran lebih mengarah pada gaya belajar kinestetik. Semua indikator keterampilan mendukung ketiga jenis gaya belajar sehingga ketercapaian hasil belajar psikomotor untuk gaya belajar auditori, visual, dan kinestetik tidak berbeda atau seimbang. 
Gaya belajar tidak berpengaruh terhadap hasil belajar biologi siswa baik pada kelas kontrol maupun kelas eksperimen. Gaya belajar merupakan faktor internal yang berasal dari dalam diri siswa. Gaya belajar siswa dipengaruhi oleh beberapa faktor, antara lain : faktor fisik, emosional, sosiologis, dan lingkungan. Hal ini sesuai dengan pendapat Rita Dunn dalam buku Deporter (2010) menyatakan bahwa terdapat banyak variabel yang mempengaruhi cara belajar orang. Ini mencangkup faktor fisik, emosional, sosiologis, dan lingkungan.

Hal ini juga didukung oleh penelitian yang dilakukan Nurochma (2012) menyatakan bahwa gaya belajar siswa tidak berpengaruh nyata terhadap hasil belajar siswa kelas VII SMP Negeri 1 Jaten tahun pelajaran 2011/2013.

\section{Interaksi strategi pembelajaran dan gaya belajar terhadap hasil belajar biologi}

Tabel 4. Interaksi Stategi Pembelajaran dan Gaya Belajar Terhadap Hasil Belajar Biologi

\begin{tabular}{lcc}
\hline Ranah & $\boldsymbol{P}$-value & Keputusan \\
\hline Kognitif & 0,538 & Ho diterima \\
Afektif & 0,716 & Ho diterima \\
Psikomotor & 0,879 & Ho diterima \\
\hline
\end{tabular}

Berdasarkan Tabel 4 menunjukkan bahwa pada hasil uji hipotesis tidak terdapat interaksi antara penggunaan strategi Active Knowledge Sharing dengan gaya belajar terhadap hasil belajar (kognitif, afektif, psikomotor).

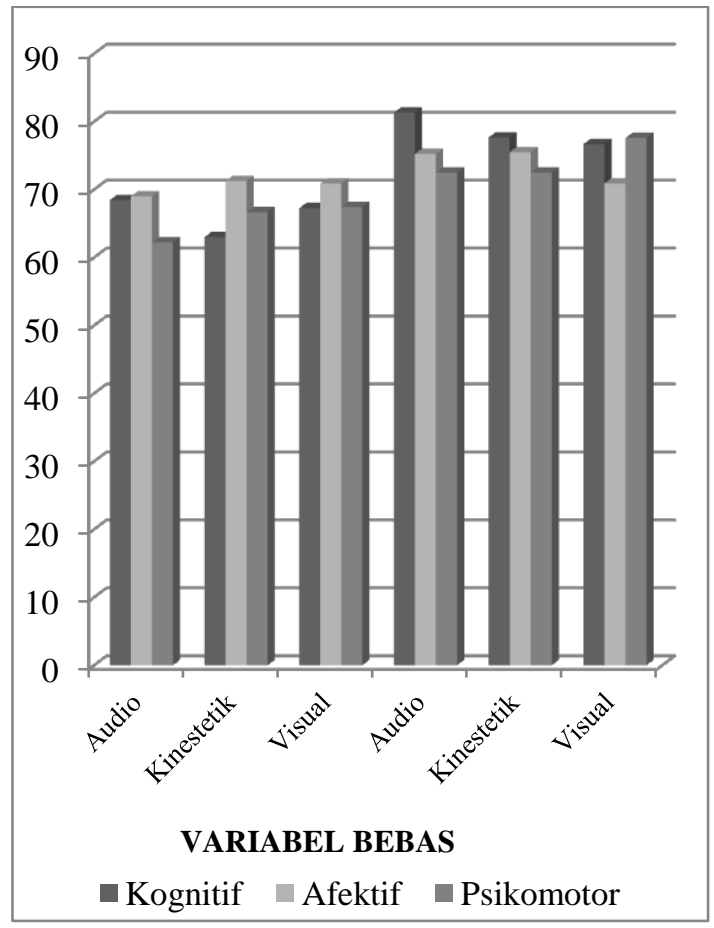

Gambar 3. Perbandingan Hasil Belajar Biologi Berdasarkan Interaksi antara Strategi Pembelajaran dan Gaya Belajar

$$
\text { Gaya belajar dan strategi }
$$
pembelajaran, masing-masing memberkan pengaruh yang berbeda pada hasil belajar. Gaya belajar membantu siswa untuk belajar secara efektif dengan cara yang tepat, sedangkan strategi hanya salah satu cara untuk mencapai hasil belajar yang optimal yang dilakukan oleh guru. Strategi pembelajaran yang diterapkan guru hendaknya mampu mengembangkan semua gaya belajar siswa dan tidak hanya mengarah pada salah satu gaya belajar. 


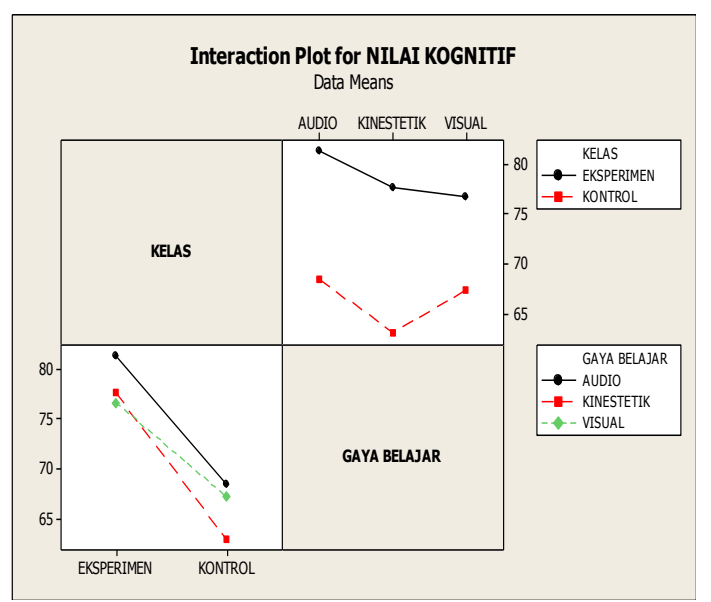

Gambar 4. Grafik Interaksi Hasil Belajar Ranah Kognitif

Berdasarkan grafik interaksi pada hasil belajar kognitif, ditinjau dari gaya belajar (auditori, kinestetik, visual) diketahui bahwa kelas eksperimen dengan Active Knowledge Sharing memiliki rata-rata nilai yang lebih baik daripada kelas kontrol dengan pembelajaran konvensional.

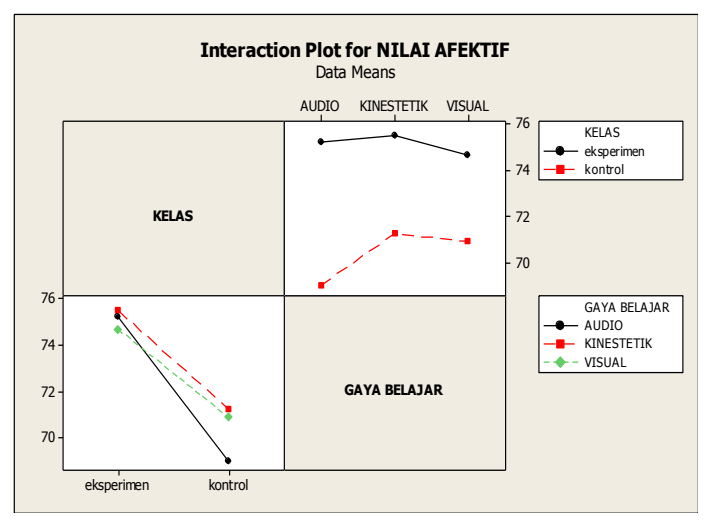

Gambar 5. Grafik Interaksi Hasil Belajar Ranah Afektif.

Dari gambar grafik di atas, pada hasil belajar afektif menunjukkan bahwa kelas eksperimen dengan pembelajaran Active Knowledge Sharing memiliki ratarata nilai yang lebih baik daripada kelas kontrol dengan pembelajaran konvensional untuk gaya belajar auditori, visual, dan kinestetik.

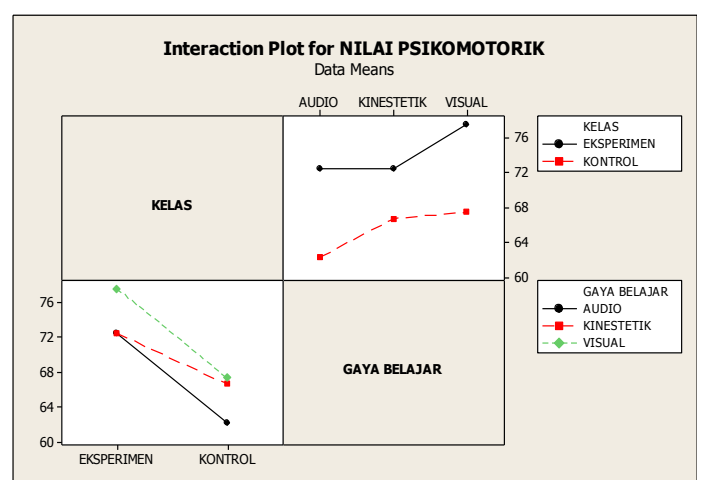

Gambar 6. Grafik Interaksi Hasil Belajar Ranah Psikomotor

Dari gambar grafik di atas, pada hasil belajar psikomotor menunjukkan bahwa kelas eksperimen dengan pembelajaran Active Knowledge Sharing memiliki rata-rata nilai yang lebih baik daripada kelas kontrol dengan pembelajaran konvensional untuk gaya belajar auditori, visual, dan kinestetik.

\section{Kesimpulan}

Berdasarkan hasil penelitian pengaruh penggunaan Active Knowledge Sharing terhadap hasil belajar biologi ditinjau dari gaya belajar siswa dapat disimpulkan sebagai berikut:

1. Penggunaan strategi Active Knowledge Sharing berpengaruh secara signifikan terhadap hasil belajar biologi (ranah kognitif, afektif dan psikomotor) siswa kelas X SMA Negeri Kebakkramat Tahun pelajaran 2012/2013. 
2. Gaya belajar tidak memberikan pengaruh yang signifikan terhadap hasil belajar biologi (ranah kognitif, afektif, dan psikomotor) siswa kelas $\mathrm{X}$ SMA Negeri Kebakkramat Tahun pelajaran 2012/2013.

3. Tidak ada interaksi antara strategi pembelajaran Active Knowledge Sharing dan gaya belajar siswa terhadap hasil belajar biologi (ranah kognitif, afektif, dan psikomotor) siswa kelas $\mathrm{X}$ SMA Negeri Kebakkramat Tahun pelajaran 2012/2013.

\section{Daftar Pustaka}

Bechina, A.A. 2006. Knowledge Sharing Practices: Analysis of Global Scandinavian Consultant Company. Electronic Journal of Knowledge Management Vol. 4 No. 2 (109-116)
Deporter, B \& Hernacki, M. 2010. Quantum Learning: Membiasakan Belajar Nyaman dan Menyenangkan. Bandung: Kaifa

Silberman, M. 1996. Active Learning 101 Strategi Pembelajaran Aktif. Yogyakarta: Pustaka Insan Madani

Nurochma, R. 2012. Pengaruh Penggunaan Pendekatan Pembelajaran Guided Inquiry Terhadap Hasil Belajar Biologi Ranah Kognitif Pada Siswa Kelas VII SMP Negeri Jaten Tahun pelajaran 2011/2013. Skripsi. Surakarta : Universitas Sebelas Maret Surakarta

Penger, S \& Tekavcic, M. 2008. Testing Dunn \& Dunn's and Honey \& Mumford's Learning Style Theories: The Case of The Slovenian Higher Education System. Management, Vol. 14, 2, 1-20

Penger,S., Tekavcic, M., \& Vlado Dimovski. 2008. Comparison, Validation And Implications Of Learning Style Theories In Higher Education In Slovenia: An experiential And Theoretical Case. Vol. 7, No. 12, 2008

Slameto. 2003. Belajar dan FaktorFaktor yang Mempengaruhi. Jakarta: Rineka Cipta 